Water Policy 2015, Vol 17, Iss 5, pp 963-983

\title{
A systematic review of success factors in the community management of rural water supplies over the past 30 years
}

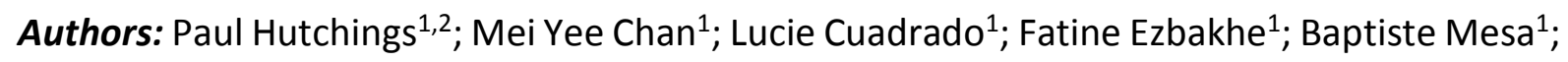
Chiaki Tamekawa ${ }^{1}$; Richard Franceys ${ }^{1}$.

${ }^{1}$ Cranfield University, Cranfield Water Science Institute, School of Applied Sciences, Vincent Building, Cranfield, Bedfordshire MK43 OAL, UK

2Corresponding author (p.t.hutchings@cranfield.ac.uk) 


\section{ABSTRACT}

Community management is the accepted management model for rural water supplies in many low and middle-income countries. However, endemic problems in the sustainability and scalability of this model are leading many to conclude we have reached the limits of an approach that is too reliant on voluntarism and informality. Accepting this criticism but recognising that many cases of success have been reported over the past 30 years, this study systematically reviews and analyses the development pattern of 174 successful community management case studies. The synthesis confirms the premise that for community management to be sustained-at-scale community institutions need a "plus" that includes long-term external support, with the majority of high performing cases involving financial support, technical advice and managerial advice. Internal community characteristics were also found to be influential in terms of success, including collective initiative, strong leadership and institutional transparency. Through a meta-analysis of success in different regions, the paper also indicates an important finding on the direct relationship between success and the prevailing socio-economic wealth in a society. This holds implications for policy and programme design with a need to consider how broad structural conditions may dictate the relative success of different forms of community management.

Key words I Community management; Participation; Rural water supply; Service delivery; Sustainability 


\section{INTRODUCTION}

Over the past three decades, community management has become the accepted management model for rural water supply (RWS) in low and middle-income countries (Schouten \& Moriarty, 2003; Harvey \& Reed, 2006; Lockwood \& Smit, 2011). During this period, the world has made great strides expanding access to improved water supply, with a further 25\% of the global population gaining access between 1995 and 2010 (World Health Organization [WHO] \& United Nations Children's Fund [UNICEF], 2012). Yet evidence from both India (Reddy et al., 2010) and Sub-Saharan Africa (Baumann, 2006) shows that around a third of rural water supply systems are non-functional raising serious questions about the effectiveness and sustainability of the community management model. Moriarty et al. (2013, p.329) argue we are now at the "beginning of the end" for community management, "not principally because community management has failed, but because it is reaching the limits of what can be realistically achieved in an approach based on informality and voluntarism." From a policy perspective, the approach falls short in two main areas: lack of long-term sustainability and lack of scalability across large projects (Bolt et al., 2001). Whilst this realisation is fuelling an examination of alternatives, including variants on public and private sector service delivery, it is also driving reform in the policies and practices of community management. Shifting the paradigm from one whereby external agencies "hand over" infrastructure to communities who take ownership and complete operation and maintenance (O\&M) duties, to a more bipartite approach in which continued support is provided by external agencies to communities (Schouten \& Moriarty, 2003; Baumann, 2006; Lockwood \& Smit, 2011; Moriarty et al., 2013). 
Baumann (2006) has labelled this transition as a move to "Community Management Plus", although other terms have also been used, including "post-construction support", "direct and indirect support", or "external support" (Kleemeier, 2000; Lockwood, 2002; Schouten \& Moriarty, 2003; Jansz, 2011; Lockwood \& Smit, 2011). Consistent across these approaches is the premise that sustainability and scalability can only be achieved if communities receive appropriate levels of institutional support, a "Plus" to sustain community water supply. By emphasising the bipartite responsibility between the community and the state (and/or other relevant agencies) throughout the service delivery cycle, community management plus challenges the existing model that had come to dominate service delivery presumptions. The conventional model emerged during the 1980s UN International Decade for Drinking Water and Sanitation based on the idea that communities should be involved in the development of water supply systems, then take ownership of them, and have overall responsibility for operation and maintenance (Harvey \& Reed, 2006; Moriarty et al., 2013). As Harvey and Reed (2006) explain, it appealed to many interests, including governments who could renounce responsibility for O\&M, bi-lateral organisations and non-governmental organisations (NGOs) who could neatly incorporate such a model into project cycles, and the prevailing cultural idealisation of rural communities as simplistic, homogenous and willing entities in service of development programmes. Whilst, at the same time, it was also underpinned by a curious mix of influential theoretical perspectives, including participatory ideas about local determination and neoliberal calls for the roll-back of the state (IRC, 2003; Blaikie, 2006; Harvey \& Reed, 2006).

However, like the public provision that preceded it, the original community management model of Village Level Operation and Maintenance (VLOM) remained broadly supply-driven 
until the 1990s. This often led to communities playing a "minor or symbolic" role in water supply with infrastructure being dumped into villages without the institutional capacity or will to effectively manage it (Breslin, 2003). In the 1990s this supposedly changed with the emergence of the demand-responsive approach (DRA) that emphasised the need for services to respond to the demand of communities, in terms of technology type, tariff levels, and management practices (World Bank, 1998; Moriarty et al., 2013). The most commonly seen incarnation of the DRA model was for communities to express initial demand through economic contributions, usually equivalent to $10 \%$ of capital costs and $100 \%$ of O\&M costs, with the remaining costs covered by external agencies, such as the State or NGOs (for an example of this financing arrangement, see the guidelines for the Government of India Swajaldhara Programme (Department for Drinking Water Supply (DWSS), 2003)). Whilst it was controversial for bringing some level of neoliberal logic into this domain, the DRA community management model continues to represent the standard declared approach for rural water supply for much of the low and middle-income world. Yet it also remains inconsistent in terms of success. Demand is highly variable across and even within communities whilst the institutional challenge of setting, enforcing and collecting funds to pay for operations and maintenance leads to a myriad of additional problems (Schouten \& Moriarty, 2003; Moriarty et al., 2013). This means the issues of inadequate sustainability and scalability in service provision have remained, with a particular breaking point occurring even in relatively well-managed schemes when large-scale investment in capital maintenance and rehabilitation is required (Lockwood \& Smit, 2011). This situation has led to the aforementioned calls for the reform of, and alternatives to, the community management model, including the emergence of community management plus. 
Recognising that although problems exist with community management there are still a significant number of cases of success, this paper seeks to systematically assess the characteristics of success in community management over the past 30 years so as to further develop the concept and practice of community management plus. Through this process it will also assess a more fundamental hypothesis: that success in the community management of rural water supply is directly related to broader socio-economic trends in a country. Building this argument, we point to the historical evidence from high-income countries which suggests an interesting correlation between economic growth and the expansion of water services (Gerlach \& Franceys, 2009). There are a number of reasons why this trend may also be apparent in terms of the community management of rural water supply. Withstanding high rates of economic inequality, growth in gross domestic product (GDP) per capita is likely to lead to higher levels of "internal financial resources" that users are able to contribute to the water supply system as well as "external financial support" from governments via either loans, grants or other funding that can be invested in water supply. Whilst, in considering the highly correlated relationship between GDP per person and broader social indicators such as literacy and numeracy (Boarini et al., 2006), economic growth is also likely to improve the overall quality of community management, with operations, maintenance and administration completed in a more professional and accountable manner. Based on this thesis, the aim of this study is to critically review and analyse the development pattern of successful community-managed rural water supplies over the past three decades across the world. Specifically, it addresses the following two questions: what "Plus" factors are associated with successful community-managed rural water supplies? And is the socio-economic setting indicative of the likely success of a community-managed rural water supply? Through this investigation the study provides a strong evidence base for policy makers and researchers on 
the type and nature of support that is required if community management plus is to be a success as well as indicative findings on the relationship between broader socio-economic conditions and the success of community management.

\section{METHODS}

Recognising the breadth of studies on community management in rural water over the past 30 years, especially in the grey literature, a systematic review with meta-analysis was selected as an appropriate approach for comprehensively synthesising the available evidence (Petticrew \& Roberts, 2006). The aim was to scan, select and systematically score all the available successful case studies of community-managed rural water supply before assessing this data against broad socio-economic trend lines. The first stage was to develop a search protocol and scan available sources for successful case studies. Searching for cases from 1980 onwards with an emphasis on both grey and academic literature, the following sources were examined via online databases: Scopus (Journal Database); African Development Bank (AfDB); Asian Development Bank (ADB); Cranfield University Library; IRC (formally the IRC International Water and Sanitation Centre); Water, Engineering and Development Centre (WEDC) Resource Centre, Loughborough University; WaterAid; World Bank Water and Sanitation Programme (WSP). For the initial search, the criteria were kept broad in order to capture as many community-managed systems as possible. A total of 2,544 potential case studies were initially found in the different sources reviewed.

To determine whether the cases were to be selected for further analysis they had to meet four basic criteria: 1) located in developing countries; 2) located in rural areas; 3) systems managed partially or entirely by the community; 4) systems functioning and delivering water to the community (at the time of the case study). The selection criteria were intentionally 
limited to just these criteria. This meant that cases were excluded from the long list in only two situations: 1) when there was not enough information in the publication to make a judgment against these criteria; 2 ) when there was enough information in the publication but the case did not meet the criteria. There was no exclusion criteria based on the methodology used to document the case study. This reflects the high number of case studies from the grey literature when methodology is not explained in sufficient detail for the researchers to make a judgment on its validity. However, due to the limited number of academic, peer-reviewed publications and the high number of publications from the grey literature on the subjects, this was considered a necessary trade-off to include a sufficient number of studies in the review. The research questions were adapted to reflect the quality of the information available, with the study aiming to provide an overview of reported success factors in successful cases whilst also assessing the indicative relationship between these success factors and wealth. As shown in Table 1 below, through this initial selection process 174 cases were selected as the primary sample from which we were to conduct further categorisation and analysis ${ }^{1}$.

\begin{tabular}{|l|l|}
\hline Region & Number of Cases \\
\hline Latin America and the Caribbean & 18 \\
\hline Middle East, North Africa, Afghanistan and Pakistan & 21 \\
\hline Sub-Saharan Africa & 79 \\
\hline Developing Asia & 56 \\
\hline Total & 174 \\
\hline
\end{tabular}

Table 1 - Number of Case Studies by Region

The case studies identified as successful in the first phase were then analysed using the "Success Framework", a qualitative tool created for this study which aimed at extracting information from the case studies according to a set of criteria. As shown in Figure 1, it

\footnotetext{
${ }^{1}$ All these documents have been uploaded to the virtual reference database Mendeley. We encourage interested parties to make use of the database. It is available at: http://www.mendeley.com/groups/4499771/rural-water-community-management-plus/
} 
included information about up to 41 different aspects of the case study, including scale, scope, technology, service levels, population characteristics, and so on. When information was not available on a particular aspect the corresponding section of the database was left blank. Using the collected information, and noting that all case studies had already been selected on the basis that they were at least a marginal success, a score between 0 and 5 was allocated, with 0 representing a marginal success (e.g. a water supply that delivers water to the community, but is not well managed nor provides good service levels) and 5 representing a full success (e.g. continuous delivery of water and the characteristics of a well-managed system).

Figure 1 - Categories in the Success Framework

Using the information from the Success Framework database, the scoring of the case studies was undertaken using a "Scoring Sheet" based on six different aspects of water service delivery. These were based on "EEVERT" (Effectiveness, Equitability, Viability, Efficiency, Replicability and Transparency) assessment principles (Franceys, 2001), which are defined as follows:

- Effectiveness: is it working/delivering water?

- Equitability: can all benefit, particularly the poorest?

- Viability: will it continue to deliver? In financial, technical and environmental terms?

- Efficiency: is it being achieved with optimum use of resources?

- Replicability: can it be repeated by others, can it be "scaled up"?

- Transparency: is it apparent/understandable to all how it works? Is there communication between the service provider and the community? 
After scoring each aspect individually, an average of all was taken as the final score for the case study. When it was not possible to score a specific "EEVERT" aspect due to lack of information, it was left unscored and not considered in the calculation of the overall score. Since the scoring method was subject to a significant amount of personal judgment (e.g. while allocating scores to each aspect), it was important to have a peer review system in place to validate consistency in the scoring process. This involved a team member reviewing and scoring case studies from each of the other reviewers. The peer review system provided a difference between scores of no more than 0.5 , which indicated that the scoring process had an acceptable degree of consistency. The outcome of this scoring phase resulted in the allocation of scores for all the 174 analysed case studies.

The scores were then mapped against broad socio-economic indicators. To select the appropriate indicator two basic criteria were taken into account: data availability (data obtainable in all years and countries of the case studies) and likely influence on progress in the rural water supply sector. Four different indicators, reflecting wealth and development of countries and their populations, were reviewed: Gross Domestic Product (Purchasing Power Parity - PPP) per capita (GDP per capita): Human Development Index Score (HDI); Revenues from water related taxes (this corresponds to the taxes deemed to be of particular relevance to water); Food prices (a measure of the international prices of a basket of food commodities). Both revenues from water related taxes and food prices were not selected because they were not available in all countries of the case studies. Whilst the HDI provides a broader socioeconomic indicator than GDP per person, both indicators strongly correlate and GDP per capita is the more readily available and recognisable indicator (Boarini et al., 2006), so it was therefore selected for use. GDP per capita data were collected from the World Economic 
Outlook database (International Monetary Fund [IMF], 2014) and were used as given, without further transformation, as the IMF data have already been adjusted to allow for international comparisons. These data were then plotted against the success scores of the case studies which were developed during the case study evaluation stage. For this purpose, the case studies were grouped into either regions or, when data allowed, specific nations. Graphs were then produced that included a double vertical axis, so that both GDP and success score could be mapped simultaneously over time. This allowed us to have a better understanding of the evolution of the success level of the case studies over the past 30 years. In the end, several graphs were constructed that showed the progress of the successful community-managed water supplies alongside the economic growth. A simple linear regression analysis was also conducted to assess the correlation between GDP per capita and the success scores from the systematic review. Together, this data visualisation and statistical analysis were used to test the hypothesis about the broad level of socio-economic development in a country or region and the likelihood of success in community management.

\section{CHARACTERISING COMMUNITY MANAGEMENT (PLUS)}

This section provides a descriptive overview of the sample. It helps clarify the characteristics of successful community management schemes and identifies key themes that emerge from reading the case studies. In terms of technology, community management is more likely to be found in cases where there is a communal water source rather than a household source. Across the sample, $50 \%$ of schemes provided water via some form of public stand-post whilst $28 \%$ supported handpumps and $22 \%$ provided household piped water supply. However, even with the majority of cases currently using relatively low-complexity technology, common problems were still identified regarding access to spare parts and technical skills for repairs. 
This was reflected in the relationship between the success of community management and the physical size of infrastructure networks, with evidence from the flagship Malawi rural piped schemes of the $1990-2000$ s suggesting that community management is more suited to smaller schemes rather than large piped networks (Warner et al., 1986; Nicol, 1998; Kleemeier, 2000; Njonjo \& Lane, 2002). The larger schemes not only required more periodic maintenance to detect and repair leaks but also better management capacity of the water committee which is a key challenge for the community management model. These results suggest that the growing emphasis on multi-village, household piped water supply schemes in lower middle-incomes countries such as India (Ministry of Drinking Water and Sanitation, 2013) is likely to pose a challenge for communitarian approaches.

Institutionally, different approaches to community management were identified, which help enrich the general model presented in the introduction. We categorise the sample into three broad typologies: 


\begin{tabular}{|c|c|c|c|}
\hline Name & Description & Characteristics & $\begin{array}{l}\text { Number } \\
\text { of } \\
\text { cases }^{2}\end{array}$ \\
\hline $\begin{array}{l}\text { Typology } 1 \\
\text { "Direct Provision } \\
\text { with Community } \\
\text { Involvement" } \\
\text { (DPCI) }\end{array}$ & $\begin{array}{l}\text { The community receives } \\
\text { direct support on finance, } \\
\text { materials and technical } \\
\text { issues from an external } \\
\text { agency and under that } \\
\text { agency's control the } \\
\text { community is partially } \\
\text { involved in O\&M. The } \\
\text { external agency is usually } \\
\text { the local government, a } \\
\text { centralised public body or, } \\
\text { on occasion, a NGO. }\end{array}$ & 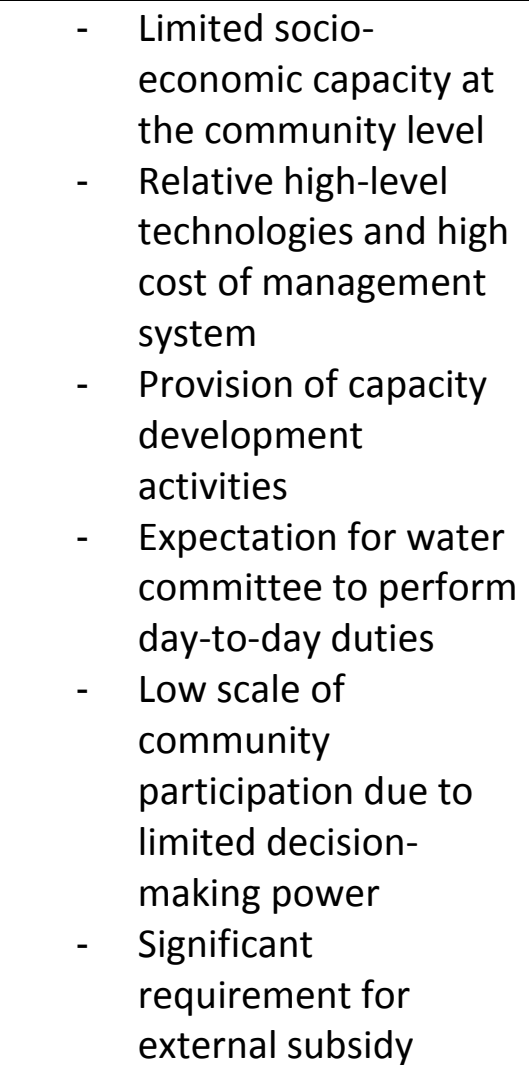 & 28 \\
\hline $\begin{array}{l}\text { Typology } 2 \\
\text { “Community } \\
\text { Management } \\
\text { Plus" (CM+) }\end{array}$ & $\begin{array}{l}\text { A community institution is } \\
\text { responsible for O\&M and } \\
\text { service provision. This } \\
\text { community institution } \\
\text { remains voluntary and may } \\
\text { not be legally recognised as } \\
\text { the service provider but } \\
\text { fulfils the role. }\end{array}$ & $\begin{array}{l}\text { - Capability of } \\
\text { management aspects } \\
\text { of system within } \\
\text { capacity of } \\
\text { community based } \\
\text { organisation (CBO) } \\
\text { - } \quad \text { Model of CBO is } \\
\text { typically an elected } \\
\text { water committee } \\
\text { carrying out all day- } \\
\text { to-day tasks of O\&M } \\
\text { and administration of } \\
\text { system } \\
\text { Sub-contract of some } \\
\text { CBO tasks to an } \\
\text { individual or local } \\
\text { company }\end{array}$ & 122 \\
\hline
\end{tabular}

\footnotetext{
${ }^{2}$ From the 174 case studies analysed, some were classified in more than one typology as they were large scale programmes where different approaches were taken depending on the circumstances of project implementation.
} 


\begin{tabular}{|c|c|c|c|c|}
\hline $\begin{array}{l}\text { Typology } 3 \\
\text { "Professional } \\
\text { Community- } \\
\text { Based } \\
\text { Management" } \\
\text { (PCBM) }\end{array}$ & $\begin{array}{l}\text { The water system is } \\
\text { operated by an authorised } \\
\text { business-like organisation } \\
\text { with a community } \\
\text { institution either taking } \\
\text { responsibility for service } \\
\text { provision in a professional } \\
\text { way or outsourcing this to } \\
\text { other entities. }\end{array}$ & & $\begin{array}{l}\text { More professional, } \\
\text { competent and } \\
\text { effective management } \\
\text { of rural water services } \\
\text { Agreed standards, } \\
\text { with greater } \\
\text { transparency and } \\
\text { accountability } \\
\text { Good business } \\
\text { practices adopted in } \\
\text { O\&M and } \\
\text { management } \\
\text { Employment of } \\
\text { trained staff }\end{array}$ & 39 \\
\hline
\end{tabular}

Table 2 - Typology of Community Management

The models presented in Table 2 were conceptualised using the principles from the Ladder of Citizen Participation (Arnstein, 1969) and associated frameworks (Adnan et al., 1992; Wilcox, 1994) that provide a well-recognised approach for assessing the degree of participation in development projects ${ }^{3}$. The research is reflective about criticisms of participation as a vague "buzzword" (Cornwall \& Brock, 2005) which becomes materialised largely as a "managerial exercise" (Cleaver, 1999) and, equally, the problematic nature of speaking of a single "community" when participation is likely to vary within and across households. Yet across the sample the type and degree of community involvement in community management was variable and the participation literature provides a framework for classifying these roles. As illustrated in Figure 2 below, the intensity of community involvement varied so that the degree of participation follows a normal distribution curve across income groups.

\footnotetext{
${ }^{3}$ The Community Water Plus Concept and Methods Working Paper (Smits et al., 2014) provides a more detailed discussion of these typologies of community management.
} 


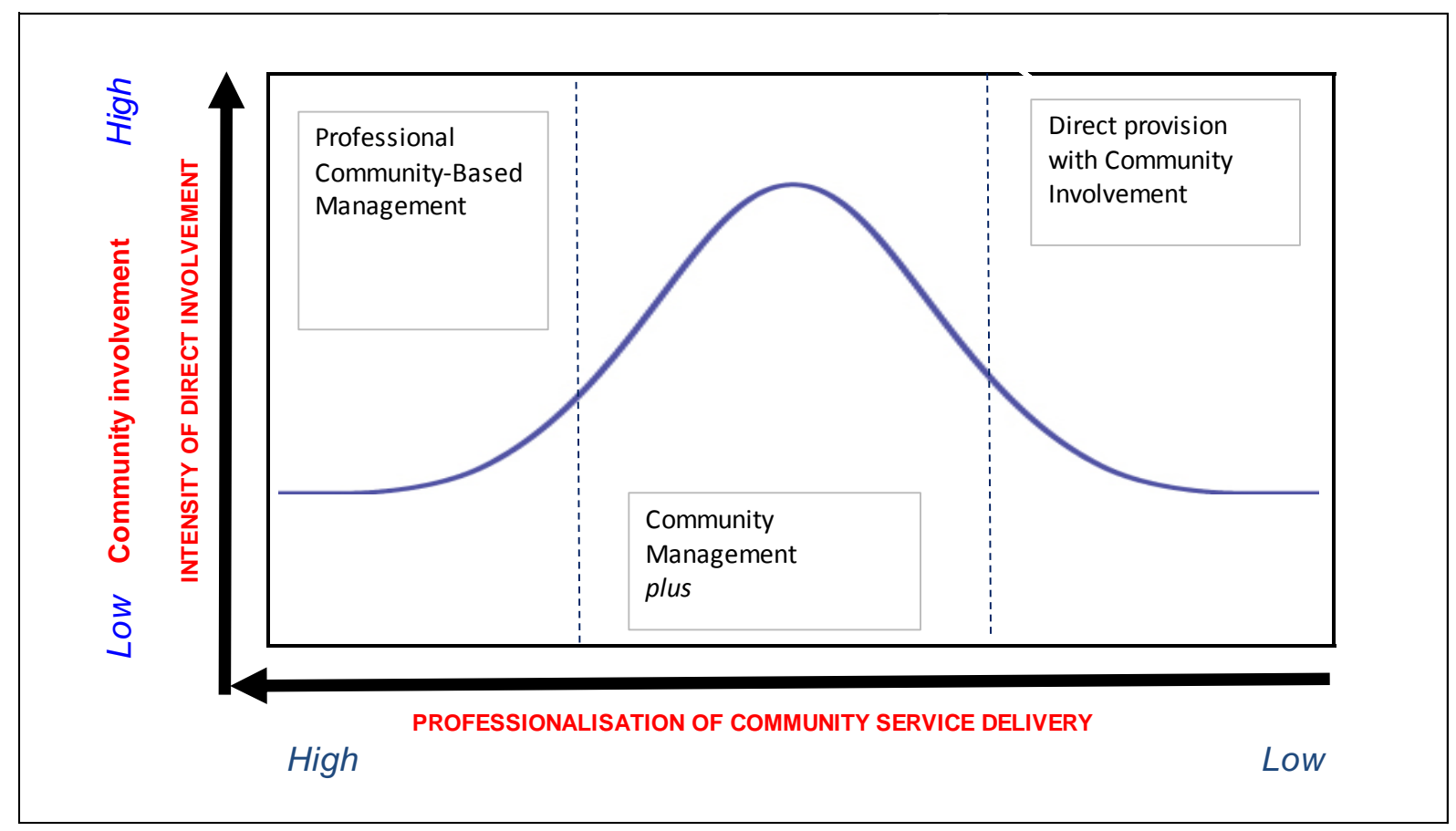

Figure 2 - Level of community involvement across different typologies of Community Management

The model shown in Figure 2 suggests that communities with higher average incomes are more likely to contribute through user charges with these funds enabling the professionalisation of the service with paid-for staff leading to the "Professional CommunityBased Management" (PCBM) consumer-orientated model. For example, the Government of Colombia Programa de Cultura Empresarial (business culture programme) supported programmes, in which the government supports a professionalised community-based service provider that adopts good business practice, such as electronic book keeping, and hires paidfor staff to take on key aspects of O\&M (Tamayo \& García, 2006). Whilst in communities with low average incomes and fragile livelihoods there is little additional capacity to contribute to the service, leading to a situation where "Direct Provision with Community Involvement" (DPCI) emerges, with community members then ideally involved in key decisions over the service but not taking responsibility for the operations and maintenance of the service. Examples of this include the Programme a'Alimentation en Eau Potable et d'Assainissenment 
en Milieu Rural (PEAMR) in Rwanda (AfDB, 2011). As part of this programme, a government entity - the Committee of Community Development - is responsible for water supply systems but works closely with the community on smaller scale schemes, whilst on larger schemes it works directly with local companies to construct and maintain systems. Communities in the middle of these groups are more likely to participate in a conventional way through the "Community Management Plus" (CM+) model with members volunteering to take on key duties including operation, maintenance and administration as well as contributing modestly through user charges. Gram Vikas, the Indian NGO working largely in the state of Odisha, provides an example of $\mathrm{CM}+$. The $\mathrm{NGO}$ delivers an intensive preparatory period of capacity building and awareness-raising in villages before assisting with the construction of a new scheme. The community then takes responsibility for O\&M with occasional call-down support provided by the NGO to the village water and sanitation committee (Thomas, 2013).

After classifying the case studies into these groups, the relationship between the length of operation, type of community management and success score was analysed. Figure 3 presents the results of the distribution of the case study scores for each typology (0-3 years, 3-5 years, and more than 5 years after initial implementation). In the DPCl category, the majority of cases were from the 0-3 years category with few scores in the higher categories of success. The distribution of cases in the $\mathrm{CM}+$ category was relatively even across project length and success scores. However, generally, higher scores are associated with longer projects, especially in the PCBM categories where nearly all case studies scored 3 or more in the more than 5 years category. 


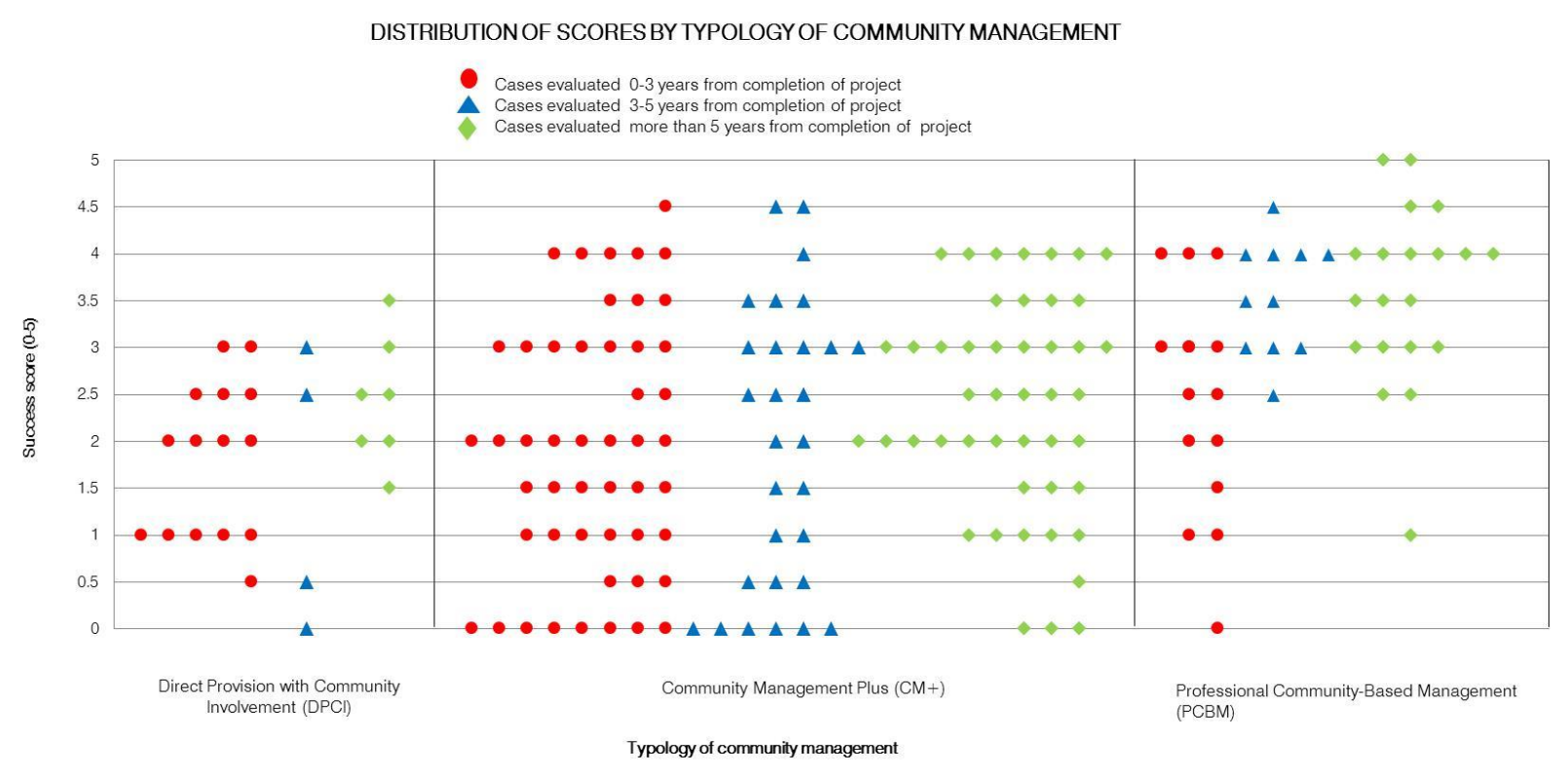

Figure 3 - Distribution of scores by typology of Community Management and numbers of years from completion In order to focus down on the plus factors that have worked in the most successful cases, we then restricted the analysis to cases which scored above 3 in the success ranking. This process left 72 cases with $8 \%$ from the DPCl category, $60 \%$ from the $\mathrm{CM}+$ typology and $32 \%$ classified as PCBM. Whilst the majority of cases are from the $\mathrm{CM}+$ typology, the proportion of cases from each category differs considerably. Twenty-nine per cent of all DPCl cases, $49 \%$ of $\mathrm{CM}+$ and $82 \%$ of PCBM made the bracket, indicating that the professionalised approach is more likely to succeed. This new sample of 72 cases were then analysed in more detail for evidence of the plus factors that had contributed to their high levels of success. This analysis indicated that it was necessary to consider plus factors in terms of internal and external factors.

\subsection{Identifying internal plus factors}

Focusing on the 72 high performing case studies, an analysis was conducted to identify the most common internal plus factors found in these successful cases. This lead to the identification of three broad themes that were classified as "collective initiative", "strong leadership" and "institutional transparency", which were deemed to be influential success 
factors across the case studies. Collective initiative was evidenced through a variety of factors including a communal ethos of self-help and responsibility, equitable participation in decision-making from across the community including women and disadvantaged groups, and a notion of shared ownership of the scheme. Strong leadership included cases when exceptional individuals or groups of individuals from the community have been able to provide supervision, monitoring and evaluation of systems and workers, as well as take the role of everyday and strategic decision makers. Institutional transparency relates to cases where accountability mechanisms are built into community institutions responsible for water supply, including democratic procedures and the disclosure of the financial and other performance data. These traits were neither mutually exclusive nor necessarily apparent in all cases of success but rather were associated with certain types of schemes and different stages of the service delivery cycle.

Following a categorisation of case studies, these three factors were then evaluated against the length of different case studies. An emphasis was placed on identifying the single most influential internal plus factor for each case study then assessing this distribution against the length of project. It was found that collective initiative was the key internal plus factor for schemes that have lasted from 0 to 5 years, but that in schemes that had lasted more than 5 years the distribution shifted to become more balanced across the categories (see Figure 4). This indicates that whilst high initiative of the community is vital for the start of the project, in order to sustain it, a more balanced approach with strong leadership and clear transparency is likely to be needed. Wider evidence shows that the bottleneck for failure in community management is likely to come some years into a project when operation and maintenance fails or capital maintenance is not fulfilled (Baumann, 2006; Harvey \& Reed, 2006; Lockwood 
\& Smit, 2011). To avoid this, water management organisations and committees need to demonstrate to the community the basis behind setting appropriate user charges or arrangements for adequate funding whilst showing clearly how this relatively large amount of money will be spent. Transparency is therefore so important for longevity because if users have doubts about the system, user charge collection systems are likely to fail. As one may expect, the review also suggests the presence of strong leadership with the right skills to manage the overall operation including human resources, management and finance, will also help drive the community in delivering sustainable services.

INTERNAL PLUS FACTORS Vs. YEARS FROM COMPLETION

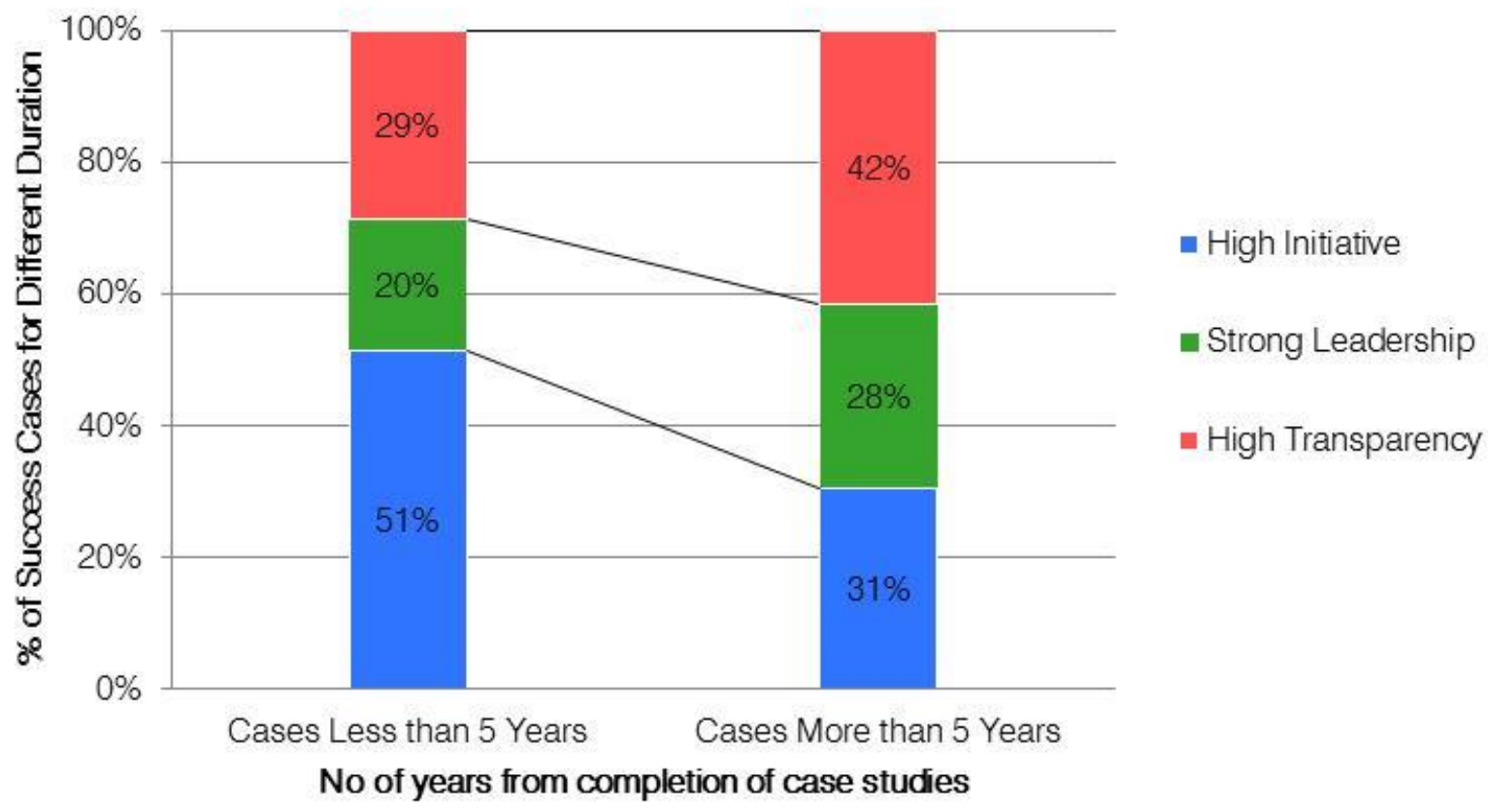

Figure 4 - Internal Plus Factors by Years from Completion

The three internal plus themes were also evaluated against management typology. Community initiative formed the building block behind the $\mathrm{CM}+$ model, yet for this model to evolve to the next stage as PCBM, transparency and leadership are needed as well. Perhaps 
surprisingly, a key factor for the DPCI model is institutional transparency. We found that in many cases, under this typology, CBOs were responsible for O\&M using funds from user charges collection. For this purpose the $\mathrm{CBOs}$ were required to report the progress of the project, especially the disclosure of the financial status to the project donors, who were subsiding the operation. This may explain why transparency was so important with the DPCI model.

\subsection{Identifying external plus factors}

Each one of the 72 most successful case studies were also analysed for external plus factors, such as the services provided by external agencies in support of community management. Unsurprisingly, finance played a critical role. As shown in Figure 5, it was found that over $90 \%$ of these high performing cases received external financial support for different expenditures (capital expenditure, operating expenditure and capital maintenance expenditure) and provision of materials from external organisations. Eight per cent of cases had access to loans and microfinance, and these cases were found particularly in Asian countries like Pakistan (Asian Development Bank, 2008; Padawangi, 2010) and China (World Bank, 2002). Capacity building for management was provided to more than half of cases and around one third could seek advice on technical issues related to O\&M from the external organisation. In total 8 main forms of external support were identified: Financial Support and Provision of Materials; Capacity Building on Technical Skills; Capacity Building on Management; Access to Advice on Technical Issues; Access to Advice on Management and Finance; Access to Loan and Microfinance; Access to Supply Chain of Spare Parts and Services; Decentralised System/Regulatory Framework which Includes Monitoring and Evaluation (M\&E). 


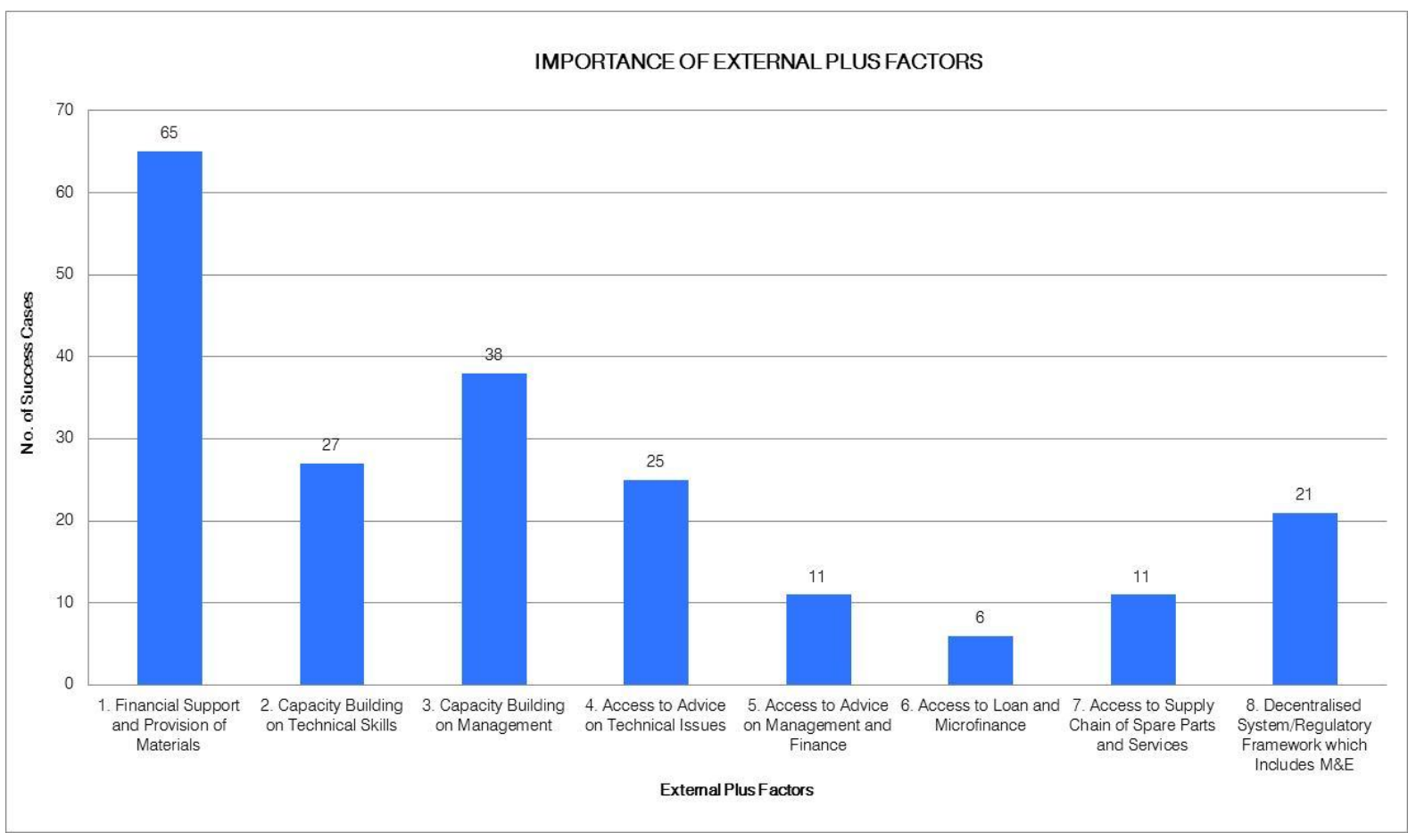

Figure 5 - Importance of External Plus Factors in most successful cases

In order to determine the importance of these external plus factors on the system's sustainability, the eight forms were evaluated based on the reported length of operations (see Figure 6). Based on the results, external factors such as "financial support and provision of materials" and "capacity building for management" were found equally important in both younger and older systems. However, cases which were less than 5 years from initiation had more access to "advice on management and finance", "loan and microfinance" "supply chain of spare parts and services" and "capacity building on technical skills". The level of external support to younger schemes may be reflective of the project cycles of many programmes, when funding and support mechanisms from implementing agencies are still available. Lastly, cases more than 5 years in length were more likely to report a "decentralised system/regulatory framework". This result indicates that the presence of governmental support through a decentralised system and reformed policies are instrumental in sustaining schemes over the longer term. 


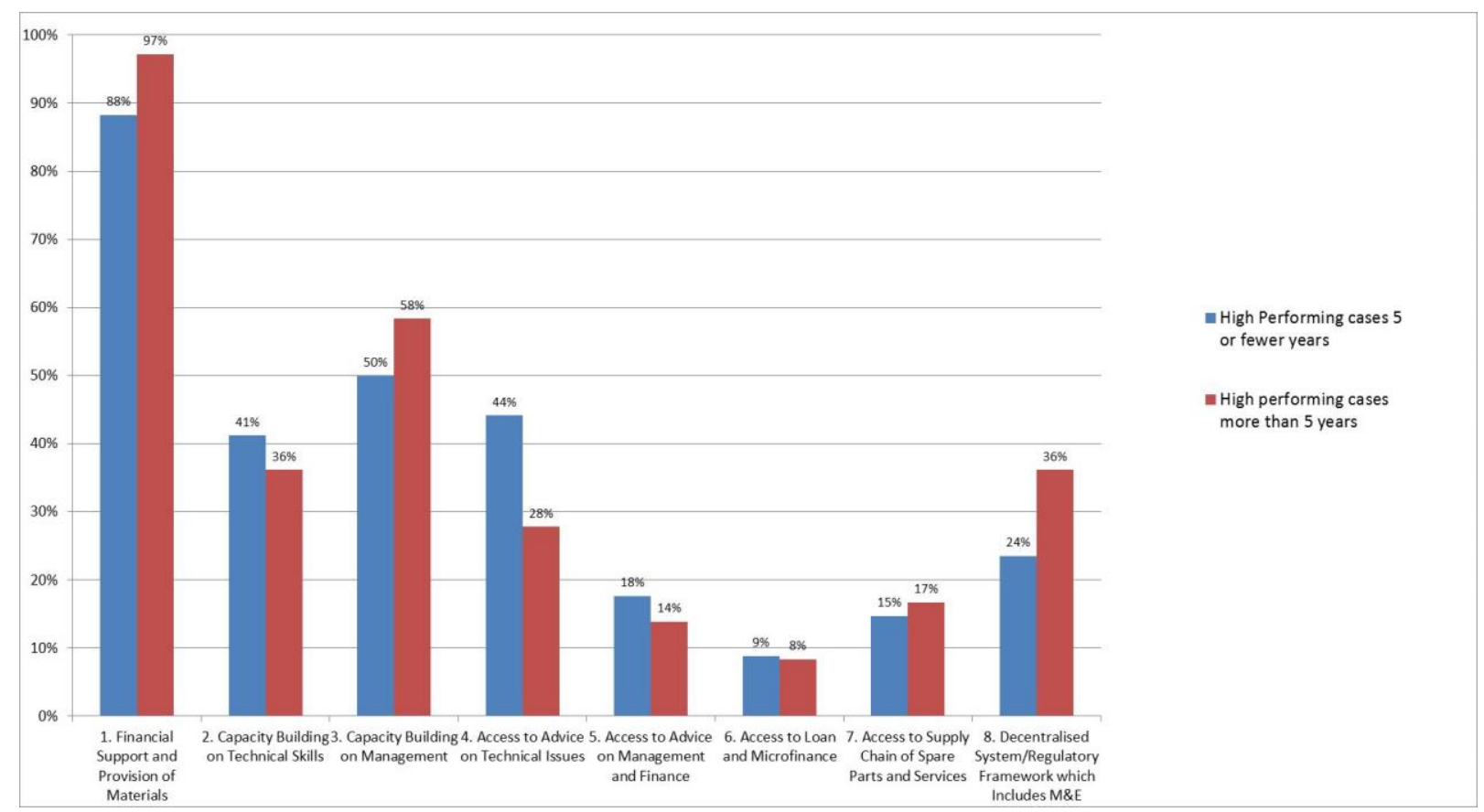

Figure 6 - External Plus Factors vs. years from completion

The eight characteristics were also evaluated based on management typology. No advice on management, access to microfinance and loan or to supply chain were observed in the DPCI model, but were observed in the other two community management types. This is likely due to the fact that external organisations tend to be in charge of most parts of the system, therefore the need to provide support to the communities is seen as less important. $\mathrm{CM}+$ appears to require various forms of external support, from financial support to advice on technical/management issues. Whilst PCBM required a broader type of enabling support (e.g. access to loans and regulatory framework). The importance of this type of broader enabling environment clearly increases when the community starts managing the water system in a more professionalised and legalised way.

\section{THE SOCIO-ECONOMIC SETTING OF SUCCESS}

In testing whether the socio-economic setting is indicative of success in community-managed rural water supply, we plotted the success scores from all the 174 case studies against GDP 
(PPP) per capita for respective regions and countries. The reported cases of success were more common after 1995 so the graphs emphasise this time period. It is unclear whether this reflects a growth in success since 1995 or the availability of published case studies from this time period. In Latin America and the Caribbean, a region with a broadly middle-income population, the data shows that the level of performance in community management has improved alongside economic growth (see Figure 7). Based on the working hypothesis, we suggest this is because internal financial resources have grown within communities, improving cost recovery. This is supported by reading the case studies, with all Latin American cases lasting five or more years, showing evidence of consistent financial contributions from users. Similarly, among most successful cases, with scores above 3 (World Bank, 2001; Davis et al., 2009; Prokopy, 2009; Whittington et al., 2009; Madrigal-Ballestero et al., 2013), four were PCBM with trained staff dedicated to the operation and maintenance of the systems and/or efficient and transparent administration. We believe such models become more common and effective as broader trends of socio-economic development occur, particular in terms of the (equitable) education of the population. 


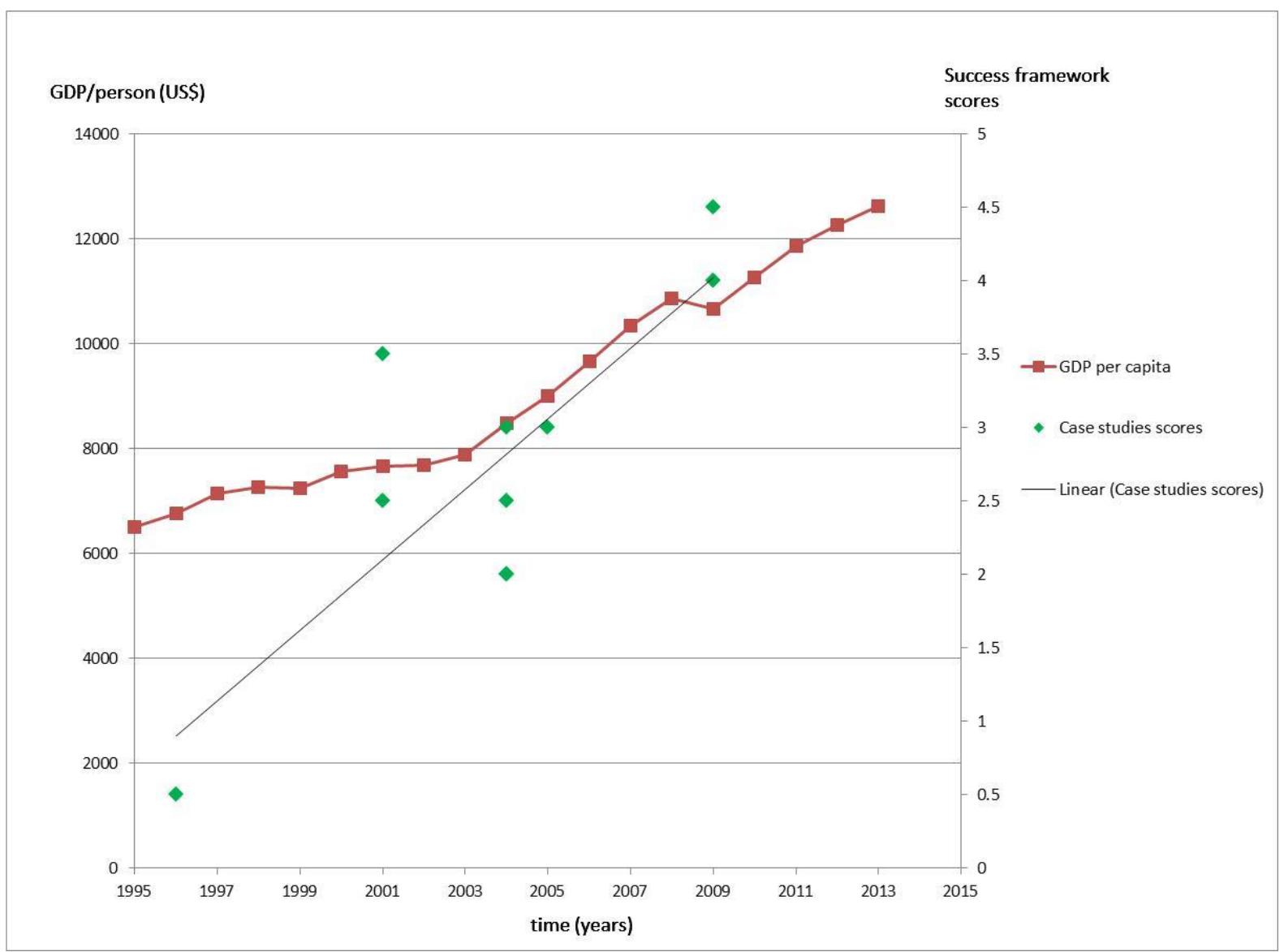

Figure 3 - Success scores vs. GDP per person in Latin America and the Caribbean

As shown in Figure 8, in India, despite the frightening inequality, there is also an indicative trend showing an improvement in the performance of community management over time. As the second most populace country globally and one that has incorporated community management principles into many state-backed programmes (Ministry of Drinking Water and Sanitation 2013), India contains a wealth of case studies. In particular, it contains internationally recognised programmes that have delivered community management at scale for over five years across populations of tens of millions including the WASMO programme in Gujarat (WASMO, 2009) and the World Bank supported Jalanidhi initiative in Kerala (Kerala State Planning Board, 2009). The move to community management in such programmes followed the Sector Reform initiatives of the early 2000s which saw an intensification and systematic expansion of community management within government policy helping to build 
an effective enabling environment in these states (James, 2011). It is notable that these principles have seen success in the generally wealthier states, such as Gujarat and Kerala, where internal and external financial resources are more plentiful. However, there are also examples of success in poorer states, although these tend to be islands of success in which highly motivated communities or programme managers have delivered success despite of broader economic indicators, such as the Gram Vikas programmes in Odisha (Thomas, 2013).

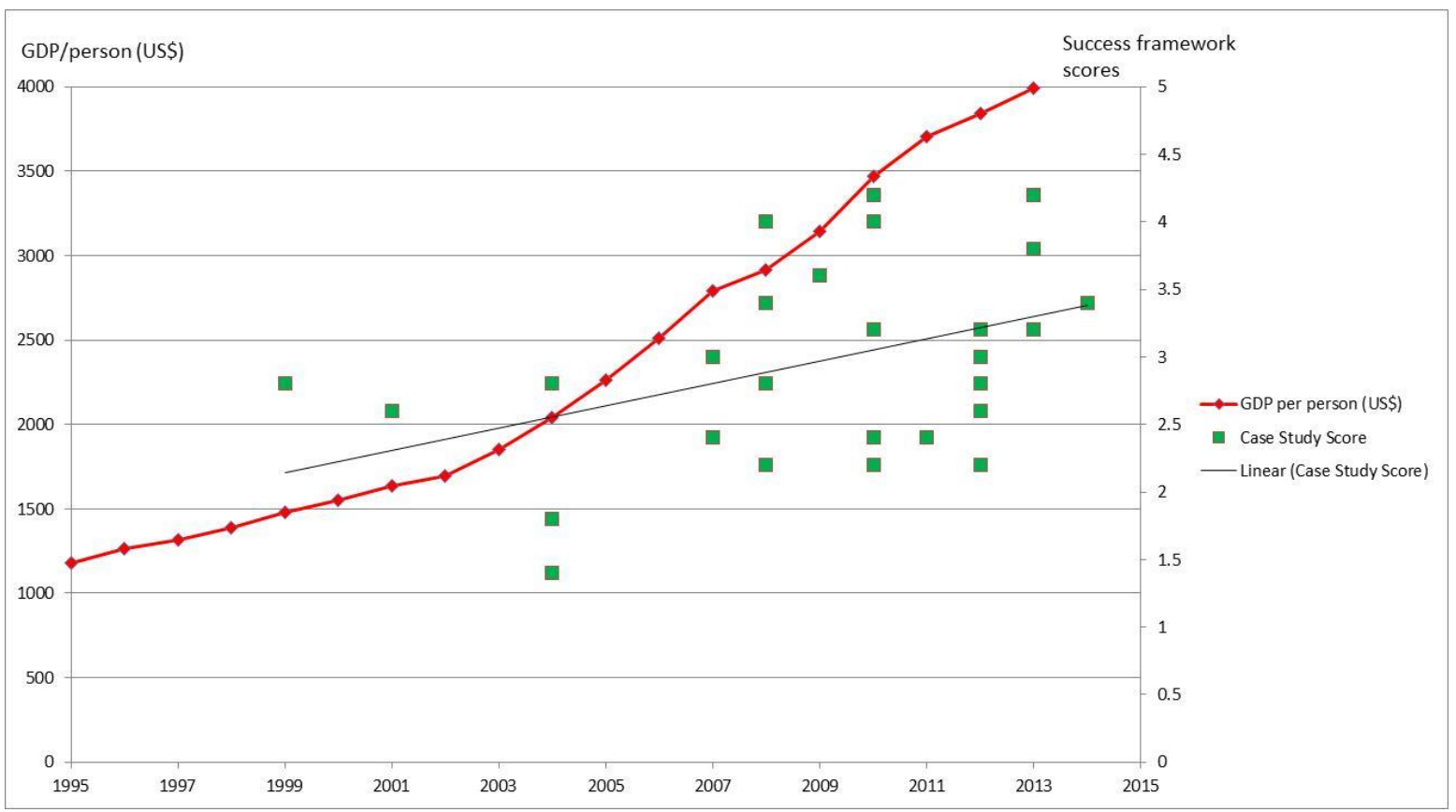

Figure 4 - Success scores vs. GDP per person in India

Whilst an indicative relationship between the socio-economic indicator and the success of case studies was visible in other regions, for Sub-Saharan Africa there appeared to be no discernible relationship (see Figure 9). Even when accounting for programmes evaluated more than 5 years after initiation, the scores were equally distributed around the mean score of 2.5 with a range of scores observed for every year, including the most recent. In part this may be explained by the high heterogeneity of the region where countries have significant differences across economies (from farming to oil production), development stages and political stability. However, the high variability of the scores over time could also be explained 
by the dependence on external support observed in the case studies. In Sub-Saharan Africa, case studies were more likely to report an absence of internal financial resources or problems with tariff setting and bill collection, whilst external support from government sources was not as common. This dependence on external support from beyond government sources would explain why Sub-Saharan Africa is not following the economic trend.

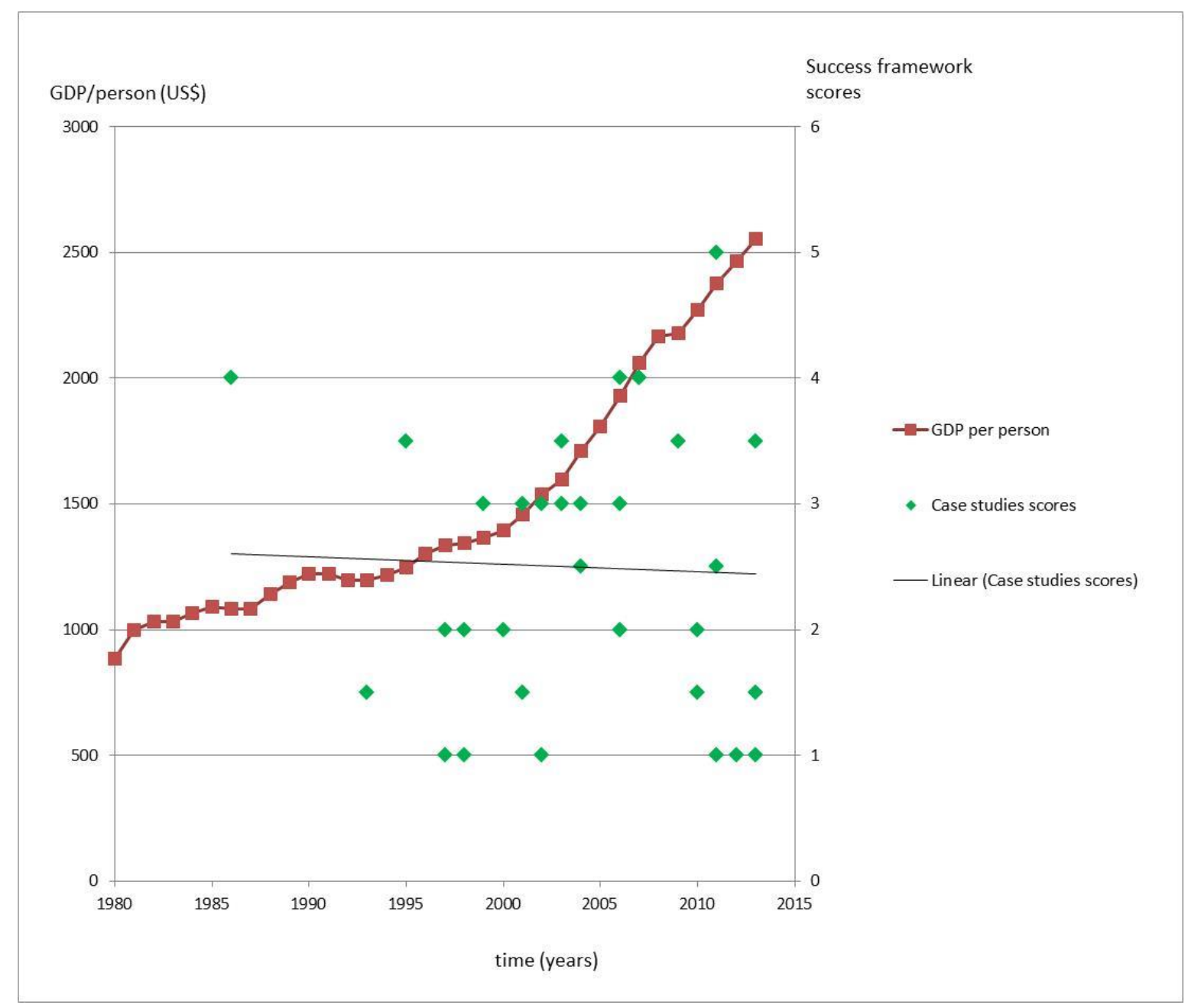

Figure 9 - Success vs. GDP per person in Sub-Saharan Africa

The fuzziness of the data presented a challenge in terms of statistical testing of the hypothesis however the basic correlation between GDP per capita and the success scores was examined using a simple linear regression for each of the major regions presented in this section. The results presented in Table 3 show that in Latin America there is a strong level of correlation 
between higher levels of GDP per capita and higher success scores. In India this relationship was weaker but there was still some evidence of correlation. However, in Sub-Saharan Africa, there was no correlation between the variables. At higher levels of GDP, the evidence supports the hypothesis that on a regional or national scale the underlying level of wealth of a society is a predictor of success in community-managed rural water supply schemes. However, at lower levels of GDP, as found in Sub-Saharan Africa, this relationship does not hold. This is likely to be explained by the high levels of international aid found in the water sectors of low-income countries which is distorting the relationship between success and wealth.

\begin{tabular}{|l|l|l|l|}
\hline & $\begin{array}{l}\text { Latin } \\
\text { America } \\
\text { and the } \\
\text { Caribbean }\end{array}$ & India & $\begin{array}{l}\text { Sub- } \\
\text { Saharan } \\
\text { Africa }\end{array}$ \\
\hline $\begin{array}{l}\text { Correlation } \\
\text { Coefficient }\end{array}$ & 0.800 & 0.411 & 0.063 \\
\hline$R$ Squared & 0.640 & 0.169 & 0.004 \\
\hline$P$ Value & 0.005 & 0.021 & 0.742 \\
\hline
\end{tabular}

Table 3 - Correlation between GDP per capita and level of success in community-managed rural water supply

\section{DISCUSSION AND IMPLICATIONS}

Research had previously emphasised the importance of internal community characteristics, such as social cohesion, as determining factors for success yet the community management plus literature has predominantly been focused on the institutional mechanisms for providing support down to communities (Schouten \& Moriarty, 2003; Baumann, 2006; Lockwood \& Smit, 2011; Moriarty et al., 2013). Whilst this paper affirms the critical role of such external support, it re-emphasises the importance of local context which must not be underestimated as a key determining factor for success. This is illustrated by locating the relative importance of internal plus factors against the length of projects. Collective initiative is particular 
important at the start of community management yet institutional transparency and leadership are the key internal characteristics for longer programmes. This has implications for authorities designing community management training programmes, with social mobilisation only a starting point that should be accompanied by periodic support that focuses on leadership development and administrative processes within community water institutions.

The review also continues to support the requirement for external support provided down to the community from a number of entities that operate in a broad "enabling environment". This sphere of support should be directly built from the higher echelons of state governments and international institutions down to local governments and other local entities. In terms of what type of support is required at the community level, a number of basic components were visible in successful cases. Over $90 \%$ of high performing cases involve financial support to the community, whilst technical advice and managerial advice are also important. Over the longer-term more complex forms of support are required, which can be broadly defined as a regulatory framework. This framework of government policies and standards is particularly critical as the wealth of populations increase and communities move along the ladder from simplistic management models to the professional management approaches found in places such as Latin America.

In considering these findings we propose a broad framework for success in community management which identifies the coming together of three interrelated components: internal plus, external plus and underlying socio-economic wealth. This model, which is visualised in Figure 10, is based on the understanding that the socio-technical system which keeps water flowing ad infinitum through capital investment, operation and maintenance, capital 
maintenance and rehabilitation requires a minimal level of economic, technical and managerial input. Depending on a range of factors, there may be sufficient community capacity to support certain elements of this input for some time, yet it is highly unlikely to be adequate to fulfil all these types of inputs, especially over the long term. Crudely speaking, low levels of "internal plus" mean that a high degree of "external plus" is required whilst high levels of "internal plus" mean a community institution will be less dependent on "external plus", although still in need of support at times. However, what this model suggests is that the capacity to provide either internal or external plus is directly related to the prevailing socio-economic wealth in a society. This is a three-fold process as increased national wealth leads to expansions in public spending on water supply, whilst household wealth results in improved payments of user charges, and overall wealth is both resultant from and a driver of institutional and economic capital throughout the population. When these conditions exist, as in some parts of Latin America and India, community management becomes more professionalised and can deliver good and lasting services. Yet, in its absence, such as is the case in large parts of Sub-Saharan Africa, community management struggles to provide longlasting services. 


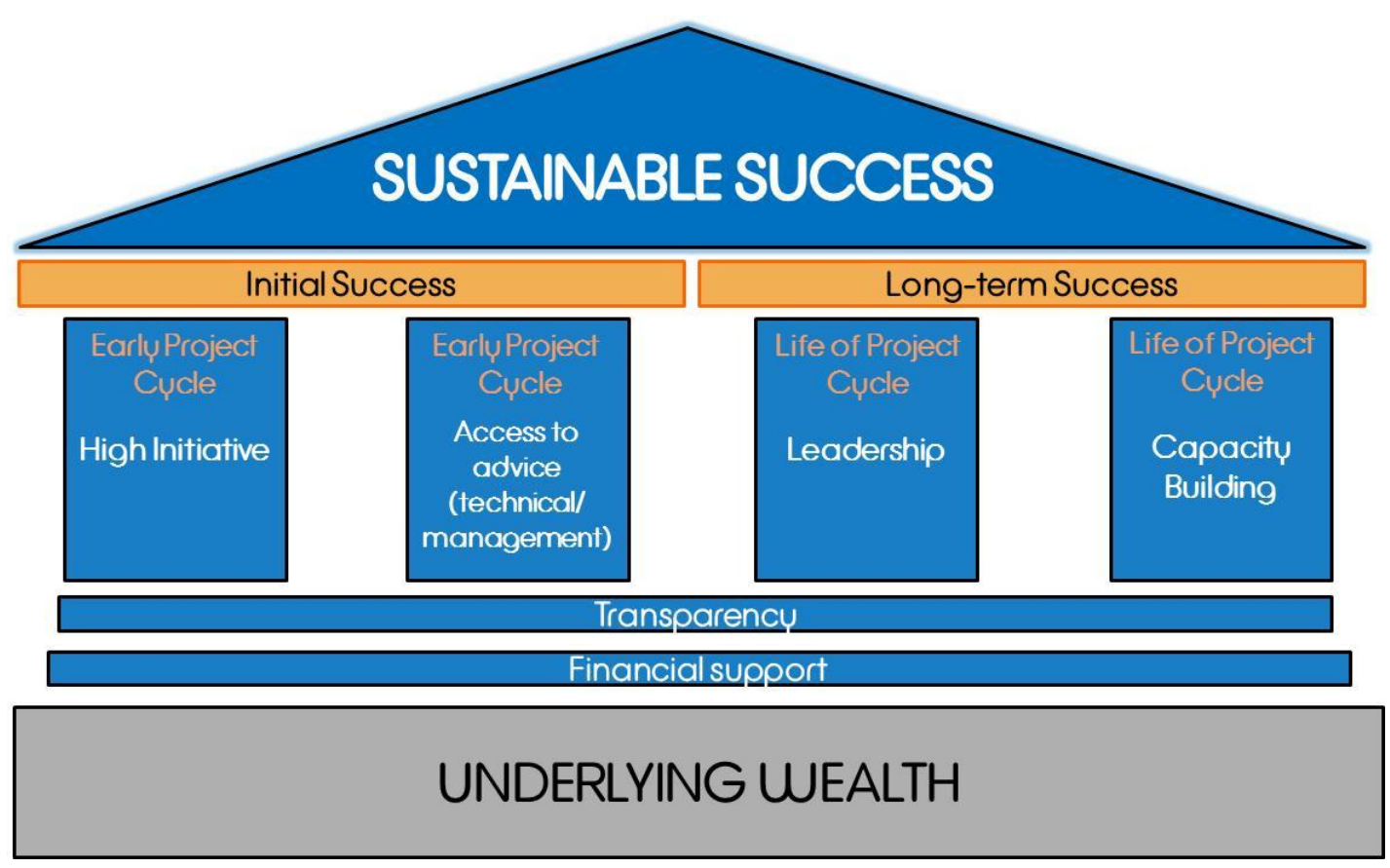

Figure 50 - Framework for success in Community Management Plus

This framework is designed to be complimentary to broader frameworks used for rural water supply, such as the "building blocks to sustainable service delivery" (Lockwood \& Smits, 2011). The building blocks model also responds to many of the problems that have been identified in this paper, including an over emphasis on infrastructure creation and a lack of long term support for community management. It identifies nine key actions that will lead to a more sustainable service delivery model for rural water supply, and whilst it does call for the professionalisation of community management, it goes beyond community management to consider broader processes of sector-level change such as the harmonisation of donor strategies. In contrast, the framework for success presented in this paper focuses on the programme level requirements in terms of support to community management. It also goes further in terms of providing insight into the conditions in which more professional forms of community management are likely to emerge by directly relating this to the broader socioeconomic conditions of a country. This last point provides what is considered a healthy dose 
of realism about the staggered and uneven transition to a more sustainable service delivery model for rural water supply.

Reflecting on the implications for policy, it is felt that enlightened programme and policy design can only create isolated success or marginally increase the rate of success in countries just above broader socio-economic trends. The external and internal inputs required to sustain water supply are directly related to these trends so there is a need to be realistic about the level of success that is achievable in certain contexts. For this reason, it is important to stop speaking of one type of community management but instead recognise the plurality of the model. For this purpose, we propose three broad typologies in which there are varying amalgamations of community involvement and external support. For example, PCBM is only likely to flourish when there is enough resource at the community level so as to enable investment in professional practices, such as electronic billing and outsourcing. A significant community contribution via tariffs tends to be a condition for success in this model, but local government still has to play a critical role building the capacity and monitoring the performance of the professionalised service providers. In contrast, $\mathrm{CM}+$ requires significant commitment at the community level which is not necessarily monetary but rather in terms of community members volunteering time toward service provision tasks. The conditions of success in this case can therefore be related to the willingness and ability of the community to take on these voluntary roles but again dedicated support from external agencies is needed, particularly in terms of technical assistance, monitoring and finance. Finally, the applicability of DPCl is related to having the necessary resources and capacity at the local government level (or other agency) so as to enable direct provision to communities, whilst recognising that limited but appropriate community involvement in operation and 
maintenance is likely to benefit the system. A key message to professionals and policy makers is that there is a need to accommodate different balances of community involvement and external support in community management programmes depending on the socio-economic context of communities. However, across all typologies, this external support is critical and will still come at a significant cost to government or other supporting agency.

\section{CONCLUSIONS}

Unacceptable failures in rural water service delivery have called into question the prominence of community management as the dominant service delivery model in the sector and yet, at the same time, community management has played a significant role in the expansion of water services to rural populations around the world in recent decades. Bringing together what initially appear contradictory statements, this paper identifies what has worked in terms of community management over the past 30 years. It shows that when community management is successful a number of internal and external elements come together to create what has been classified as a "plus" to the standard community management model. This confirms the premise that the "classic" approach to community management is no longer adequate (if it ever was) and that for community management to be sustained-at-scale community institutions need extensive, long-term support.

The research links the presence of these internal and external success factors with the broad levels of socio-economic development found in populations. In Latin American and the Caribbean and to a lesser extent India, the growth in resources available at either the household or government level appears to be leading to an improvement in the overall levels of success in the community management model. However, in the lower-income region of Sub-Saharan Africa, no relationship was observable between the success of community 
management and the level of GDP per capita. This was thought to be explained by the high levels of international subsidy channelled into projects across Sub-Saharan Africa that distorts the relationship between success in rural water supply and national wealth. This raises a set of important question for future research: do success factors differ in aid-supported water programmes versus programmes funded through national or local resources? And can support strategies be developed to accelerate the performance of rural water supply programmes above socio-economic trend lines? Data permitting there would also be value in further differentiating between low income fragile states and low income stable states, which may go some way to explaining the lack of correlation between success and GDP per capita in Sub-Saharan Africa.

Concluding, we stress that a commitment to community management for rural water supply should be wholly pragmatic and not ideological. As both personal and public finances grow around the world, properly funded public provision or private sector models may become viable, yet it is likely that community management plus remains an appropriate and effective delivery model for some areas. The emerging realisation is that it is not a form of service delivery "on the cheap" but that external agencies need to play an extensive role in a bipartite relationship with the community, one that is continuous and lasts, and which involves serious commitment in terms of investment in support institutions. This may challenge the culture of project cycles that the development sector follows and, going forward, to help the sector realign there remains a need for better information on the true costs of such support services.

\section{ACKNOWLEDGEMENTS}

This research forms part of the Community Water ${ }^{\text {Plus }}$ (Community management of rural water supply systems) three year research project funded by the Department of Foreign Affairs and 
Trade (DFAT) of the Australian Government as part of the Australian AID Development Awards

Research Scheme. The major empirical focus of the Community Water Plus project is rural water supply in India but this paper forms part of the broader global literature review and scanning process undertaken as part of this project. The authors would like to thank two anonymous reviewers for their useful comments on an earlier draft of this paper.

\section{REFERENCES}

Adnan, S., Barrett, A., Alam, S. M. N., \& Brustinow, A. (1992). People's participation, NGOs, and the Flood Action Plan: an independent review. Oxfam-Bangladesh Research \& Advisory Services, Dhaka, Bangladesh.

African Development Bank. (2011). Rwanda - Programme d'alimentation en eau potable et d'assainissement en milieu rural (PNEAR) - Rapport d'Achevement de Programme (RAP). Retrieved from http://www.afdb.org/fileadmin/uploads/afdb/Documents/Project-andOperations/RWANDA-

Programme d\%E2\%80\%99Alimentation en Eau Potable et d\%E2\%80\%99Assainissement en Milieu

Rural - PNEAR (Premier Sous-program-me)-11-05-2010.pdf

Arnstein, S. R. (1969). A ladder of citizen participation. Journal of the American Institute of Planners, 35(4), 216-224.

Asian Development Bank (2008). Pakistan Punjab Community Water Supply and Sanitation Sector Project. Independent Evaluation Department Asian Development Bank, Manila, Philippines.

Baumann, E. (2006). Do operation and maintenance pay? Waterlines, 25(1), 10-12.

Boarini, R., Johansson, Å., \& d'Ercole, M. M. (2006). Alternative Measures of Well-Being. OECD Economics Department Working Papers. OECD, Paris, France.

Bolt, E., Schouten, T., \& Moriarty, P. (2001). From Systems for Service: Scaling Up Community Management. In: U. WEDC, Loughborough University (ed). 27th WEDC Conference - People and Systems for Water, Sanitation and Health. Lusaka, Zambia.

Breslin, E. D. (2003) The demand-responsive approach in Mozambique: why choice of technology matters. Waterfront. Iss 16. Fall 2003. UNICEF. New York. [PH2]

Cleaver, F. (1999). Paradoxes of participation: questioning participatory approaches to development. Journal of International Development, 11(4), 597-612. 
Cornwall, A. \& Brock, K. (2005). What do buzzwords do for development policy? A critical look at "participation", "empowerment" and "poverty reduction." Third World Quarterly, 26(7), 1043-1060.

Davis, J., Lukacs, H., Jeuland, M., Alvestegui, A., Soto, B., Lizárraga, G., Bakalian, A. \& Wakeman, W. (2009). Sustaining the Benefits of Rural Water Supply Investments: experience in Cochabamba and Chuquisaca, Bolivia. In: Post-Construction Support and Sustainability in Community-Managed Rural Water Supply: Case Studies in Peru, Bolivia, and Ghana. Bakalian, A. \& Wakeman, W. (eds). World Bank - Netherlands Water Partnership, Washington DC, USA.

DDWS. (2003). Swajaldhara Guidelines. Department for Drinking Water Supply. Government of India. New Delhi.

Franceys, R. (2001). Promoting international scientific and technological co-operation in sustainable water and sanitation. In: OECD Conference on International Scientific and Technological Co-operation for Sustainable Development. Seoul, South Korea.

Gerlach, E. \& Franceys, R. (2009). "Standpipes and beyond"-a universal water service dynamic. Journal of International Development, 22(4), 455-469.

Harvey, P. A. \& Reed, R. A. (2006). Community-managed water supplies in Africa: sustainable or dispensable? Community Development Journal, 42(3), 365-378.

IMF (2014). World Economic Outlook Database. Available from: http://www.imf.org/external/pubs/ft/weo/2014/01/weodata/index.aspx.

IRC. (2003). Community Water Supply Management: History of a Concept. IRC. Delft (Netherlands). [PH2]

Jansz, S. (2011). A study into rural water supply sustainability in Niassa province, Mozambique. WaterAid. London, UK.

Kerala State Planning Board (2009). An Evaluation Study on Jalanidhi Projects in Kerala. Government of Kerala, Thiruvananthapuram, Kerala.

Kleemeier, E. (2000). The impact of participation on sustainability: an analysis of the Malawi rural piped scheme program. World Development, 28(5), 929-944.

Lockwood, H. (2002). Institutional Support Mechanisms for Community-managed Rural Water Supply and Sanitation Systems in Latin America. USAID. Washington DC, USA.

Lockwood, H. \& Smit, S. (2011). Supporting Rural Water Supply: Moving Towards a Service Delivery Approach. Practical Action Publishing Ltd, Warwickshire, UK. 
Madrigal-Ballestero, R., Alpízar, F., \& Schlüter, A. (2013). Public perceptions of the performance of community-based drinking water organizations in Costa Rica. Water Resources and Rural Development, 1-2, 43-56.

Ministry of Drinking Water and Sanitation (2013). National Rural Drinking Water Programme, Rajiv Gandhi Drinking Water Mission, Movement towards ensuring people's Drinking Water Security in Rural India, Framework for Implementation (updated 2013). Government of India. New Delhi, India.

Moriarty, P., Smits, S., Butterworth, J., \& Franceys, R. (2013b). Trends in rural water supply: towards a service delivery approach. Water Alternatives, 6(3), 329-349.

Nicol, A. (1998). Mchinji Water Project, Malawi. In: Lessons Learned from NGO Experiences in the Water and Sanitation Sector. Smout, I. \& Parry-Jones, S. (eds). WEDC, Loughborough University, UK, pp. 63-65.

Njonjo, A. \& Lane, J. (2002). Rural Piped Water Supplies in Ethiopia, Malawi and Kenya: Community Management and Sustainability. Water and Sanitation Program - Africa region field note (13). World Bank, Washington, DC.

Padawangi, R. (2010). Community-driven development as a driver of change: water supply and sanitation projects in rural Punjab, Pakistan. Water Policy, 12(S1), pp. 104-120.

Petticrew, M. \& Roberts, H. (2006). Systematic Reviews in the Social Sciences. Petticrew, M. \& Roberts, H. (eds). Blackwell Publishing Ltd, Oxford, UK.

Pretty, J. (1994). Alternative systems of inquiry for a sustainable agriculture. IDS Bulletin, 25, 37-49.

Prokopy, L. S. (2009). Determinants and benefits of household level participation in rural drinking water projects in India. Journal of Development Studies, 45(4), 471-495.

Reddy, V. R., Ramamohan Roa, M. S., \& Venkataswamy, M. (2010). "Slippage": The Bane of Rural Drinking Water Sector (A Study of Extent and Causes in Andhra Pradesh). 6. WASHCost (India).

Schouten, T. \& Moriarty, P. (2003). Community Water, Community Management. From System to Service in Rural Areas. ITDG Publishing, London.

Smit, S. Franceys, F. Mekala, S., \& Hutchings, P. (2014). Understanding the resource implications of the "plus" in community of rural water supply systems in India: concepts and research methodology (Unpublished Manuscript). Community Water Plus. To be available from: http://www.ircwash.org/projects/india-community-water-plus-project

Tamayo, S. P. \& García, M., 2006. Estrategia estatal para el fortalecimiento de entes prestadores de servicios públicos en el pequeño municipio y la zona rural. El programa cultura empresarial adelantado en Colombia. In: Apoyo a la gestión de Comités de Agua 
Potable; experiencias de fortalecimiento a comités de agua potable con gestión comunitaria en Bolivia y Colombia. Quiroz, F., Faysse, N., \& Ampuero, R. (eds). Centro Agua - UMSS, Cochabamba, Bolivia.

Thomas, S. K. (2013). Gram Vikas - An Overview. Presented at Community Water Plus Stakeholder Meeting, New Delhi, India.

Warner, D. B., Briscoe, J., Hafner, C., \& Zellmer, B. (1986). Malawi self-help rural water supply program: final evaluation Water and Sanitation for Health Project (WASH). Arlington, VA, USA.

WASMO (2009). From Policy to Practice: Users as Managers of Rural Drinking Water Supply Systems. Water and Sanitation Management Organisation (WASMO), Gandhinagar, Gujarat.

Whittington, D., Davis, J., Prokopy, L., Komives, K., Thorsten, R., Lukacs, H., Bakalian, A., \& Wakeman, W. (2009). How well is the demand-driven, community management model for rural water supply systems doing? Evidence from Bolivia, Peru and Ghana. Water Policy, 11(6), 696-718.

WHO \& UNICEF (2012). Progress on drinking water and sanitation 2012 update. UNICEF and World Health Organization, USA.

Wilcox, D. (1994). The Guide to Effective Participation. Partnership Books, London.

World Bank (2001). La asociacion de usuarios en la gestion de servicios de agua en localidades rurales multiples: el caso de el Ingenio en Ica, Nasca, Perú. World Bank Water and Sanitation Program - Andean Region, Washington, DC.

World Bank (2002). Willingness to charge and willingness to pay: the World Bank-assisted China rural water supply and sanitation program. World Bank Water and Sanitation Program, Washington, DC.

Received 3 July 2014; accepted in revised form 17 January 2015. Available online

Published by Water Policy. This is the Author Accepted M anuscript issued with:

Creative Commons Attribution Non-Commercial License (CC:BY:NC). 